\title{
A short history of the Science and Mathematics Education Centre at Curtin University
}

\section{David F Treagust}

Received: 20 April 2011 / Accepted: 21 May 2011

\begin{abstract}
This article is presented in four parts. In the first part, I describe the foundation of the Science and Mathematics Education Centre (SMEC) at Curtin University. In the second part, I explain the development of SMEC's teaching and research capacity under its three directors. In the third section, I describe how federal government support of SMEC as a national Key Centre for Teaching and Research in School Science and Mathematics provided enhanced postgraduate study opportunities for science and mathematics teachers throughout Australia by offering degree programs through distance education and face-to-face contact, short courses, and seminars. At the same time, research and teaching capacity of the academic staff was enhanced through the internationalisation of the programs being offered. In the final section, I describe current and future developments at SMEC.
\end{abstract}

Keywords Teaching philosophy · Research agendas · Gender equity · Graduate education • Globalisation

\section{The foundation of the Science and Mathematics Education Centre (SMEC)}

Many science education researchers will know the names of Curtin University academics, Barry Fraser, Ken Tobin, Leonie Rennie, Darrell Fisher, David Treagust and Peter Taylor from the SMEC. However, these same researchers will not have heard or read the work of John de Laeter. This is not surprising as de Laeter (1933-2010) was an eminent physicist who did not attend science education research conferences. However, de Laeter has had an enduring passion for the promotion of high-quality science teaching and learning and the origins of the SMEC at Curtin University are testament to this passion. As a physicist, de Laeter's research in geological mapping of mineral-rich Western Australia aided exploration after the 1970s and his internationally acclaimed physics research on mass spectrometry was used to address astrophysical, chemical, geological and nuclear problems. de Laeter helped create the Technology Park next to Curtin University and the Science and Technology Centre (Scitech) in Perth as well as being the founder of the SMEC at Curtin University.

D. Treagust ( $\triangle$ )

Science and Mathematics Education Centre

Curtin University of Technology, Perth, Australia

d.treagust@curtin.edu.au 
The founding of the SMEC in the late 1970s was the result of four issues that de Laeter was able to bring together. The first issue was related to the outcomes of a 1970s initiative about schools' laboratory science; the second was that the Physics Department in the recently created Western Australian Institute of Technology (WAIT) had many former high school teachers on the staff who had an interest in physics, mathematics, chemistry and biological education. The third issue was that as Dean of Science, de Laeter could influence how resources were used within WAIT. The fourth issue was the creation of a philosophy of teaching in higher education that at the time was very innovative.

In the early to mid 1970s, the Commonwealth Government recognized that Australia's future was dependent on science and funds were made available for building new science laboratories in both government and independent schools. A Science Laboratories Committee for Independent Secondary Schools was set up in the late 1960s comprising one person from each State. The laboratories in secondary school, particularly in independent (nongovernment) schools, at that time were not well established and federal money was needed to upgrade them. The task of the Committee was to produce booklets with designs for science laboratories (Commonwealth Advisory Committee on Standards for Science Facilities in Independent Secondary Schools 1971) and a list of essential equipment (Commonwealth Advisory Committee on Standards for Science Facilities in Independent Secondary Schools 1974). Subsequently, schools throughout Australia had new science laboratories. However, following a review of the implementation of the laboratory program, although there was some improvement in science education in Australian independent schools, by and large the improvements were deemed not to be commensurate with the money that had been expended (Wordsworth et al. 1975).

A second consideration for improving science education was to provide continuing education for science and mathematics teachers. de Laeter, who at the time was head of the Department of Physics at the then Western Australian Institute of Technology, and other scientists holding similar positions in Australian universities presented such a recommendation. Fortuitously, when de Laeter became Dean of Science in 1974, there was a great interest in physics, mathematics, chemistry and biological education with embryonic physics education, chemistry education, biology education, and mathematics education graduate degrees in the different science and mathematics departments, physics education being the most advanced. 
With the creation of newly formed Science Education Centre (which later became the SMEC) was the need to appoint a Director. David Boud, a physicist working in the UK, was invited to be the head of this embryonic Science Education Centre. The fourth issue, of central importance to SMEC, was its underpinning philosophy, which owed much to de Laeter and Boud. de Laeter believed that science teachers, after they had been teaching for a few years, would gradually lose contact with developments in their science, and there should be an opportunity for them to come back to university and bring themselves up-to-date. de Laeter's explanation of SMEC's teaching philosophy was based on his own postgraduate education in physics and in education and his experiences as a secondary school physics teacher and a physics researcher. He believed that postgraduate science education should operate in a science faculty rather than an education faculty, and should cater for science teachers who wished to study on a part-time basis. In this way, teachers were provided with opportunities to become up-to-date in their science or their mathematics, in addition to science education or mathematics education, and learn about topics that would be of value for teaching in their classrooms.

Subsequently, a course was designed to be of practical value, with hands-on experiences, leading to a Graduate Diploma in Science Education (two years part-time) followed by a Master's degree course including the completion of a research thesis (also two years parttime). This program proved very popular with local science and mathematics teachers in Perth. The most distinctive feature of this continuing science and mathematics education was that the group of lecturers and teachers were coming together as experienced people and colleagues because all were science teachers with some years of experience. Therefore, the philosophy developed was that the lecturers (in the beginning Boud and de Laeter) would learn as much from the group of teachers as, hopefully, the teachers would learn from them (see Boud and de Laeter 1978).

So the students - the science teachers - were treated as adults, experienced people with a real knowledge of the field of science education - probably having better knowledge than the lecturers - and together they would learn by creating a combined vision of quality science education. In de Laeter's own words:

So we used to sit down with the group at the beginning of semester and say "Well, what are the sorts of things that you would like to know?” And we would go through and work out a syllabus, and we'd decide who was going to teach it; and that meant 
which students were going to teach, not whether it was Dave Boud or myself. Also, the evaluation of the students involved an assessment by their peers.

The outcome of this vision, the jointly designed and presented course, including the peer assessment, was valued because the people within it were valued; this was a true sharing of experience, of ideas, and of commitment to science and science teaching.

Over more than three decades, the philosophy of SMEC has remained true to the original goals initiated by de Laeter. Postgraduate students, who are science and mathematics teachers or university academics from Australia and many overseas countries, are treated as professionals in their own right; lecturers and the postgraduate students both make significant contributions to the classes. SMEC has a vastly different group of postgraduate students from those early days but we still teach in this manner. de Laeter's influence about teaching postgraduate classes has been felt in the many countries where SMEC has students. SMEC staff, along with our many past students, remains grateful and appreciative of his legacy.

\section{Developing teaching and research capacity}

There have only been three Directors in the life of SMEC. When Boud left WAIT for a position at the University of New South Wales in 1979, John Dekkers from Queensland was appointed as the new Director. Dekkers was a chemist with a PhD from the Australian National University and was very interested in science education. Under guidance from de Laeter, Dekkers continued with the same teaching philosophy and the Centre continued to prosper. During this period Mike O’Loughlin, David Treagust and John Malone were appointed to SMEC. One of the major accomplishments during Dekkers' directorship was the development of external studies such that teachers who taught in schools in regions outside Perth could study for both the Postgraduate Diploma and the Master's degree. SMEC's programs for the coursework Postgraduate Diploma and the Master's thesis could be studied using materials developed by SMEC staff and sent to students by the Department of External Studies. In addition to hard copy materials and books sent to students, initially in Western Australia, and later in other areas throughout Australia, the then existing satellite technology was used to communicate with students in various locations around Australia. 
Dekkers was enthusiastic and supportive about SMEC staff and students presenting their research work at major national conferences in Australia and thereby increasing other colleagues' awareness of the research activities at SMEC. Also under Dekkers' directorship, visiting academics such as Joe Novak (Cornell University, USA), Vince Lunetta (Pennsylvania State University, USA) and Fred Reif (University of California at Berkeley) came to the Centre and gave workshops to local science and mathematics teachers at SMEC and went on to other universities in Australia (or in the case of Lunetta to work with Ed van den Berg in Indonesia) to conduct similar workshops.

The appointment of Barry Fraser, as the third Director of SMEC, enabled more interactions between the Faculty of Science and the Faculty of Education, thereby fostering important connections between academics in the two faculties. A year or so earlier, Fraser had been recruited from Macquarie University in Sydney and appointed to the Head of Curriculum Studies in the Faculty of Education at WAIT. From 1984 until 1988, Fraser held a joint appointment in the Faculty of Education and as Director of SMEC. During the first few years as Director, Fraser took on the task of building the teaching and research capacity at SMEC. In 1984, Ken Tobin was appointed a Senior Lecturer, being recruited from Edith Cowan University in Perth, and subsequently three years later took an appointment at Florida State University. Léonie Rennie joined SMEC as Senior Lecturer from the University of Western Australia in 1988 having been in the Faculty of Education there since 1973. In 1985, Peter Taylor was appointed as a Research Fellow to work on the development of bridging programs for Aboriginal students wishing to gain access to undergraduate science and mathematics courses. Taylor later became an academic staff member and is now Associate Professor, having developed a strong research agenda in transformative education to complement those of existing staff. From the beginning of his tenure, by providing the necessary intellectual environment, Fraser encouraged each staff member to develop his or her research agenda that included doctoral students. Also Fraser built up the national activities of SMEC (as opposed to being within the State) and greatly enhanced international connections and activities. These aspects are described more fully in the next section.

\section{Creating a national program and developing international contacts}

Under Fraser's entrepreneurial and creative leadership, SMEC took on a new role to broaden the student base. Initially, this involved the development of Master's degrees by coursework and project - in addition to the Master's by thesis - and recruiting more teachers to study at 
WAIT and also to increase the number studying in the external mode. Having a relatively large number of students not only throughout Western Australia, but also in other states and territories, provided the basis for becoming a federally-funded national key centre described below.

During this period, under the leadership of the President/Vice Chancellor Don Watts, WAIT independently became Curtin University of Technology, named after Australia's secondworld-war time Prime Minister, John Curtin, who was born and lived in Perth (see White 1988). In 1987, the federal government designated all Institutes of Technology to become universities. Prior to this time, the University of Western Australia awarded doctoral degrees for studies conducted at WAIT. As a university, Curtin could now offer doctoral degrees. As SMEC was well established with postgraduate research Master's degrees, it was a relatively straightforward process to develop and offer doctoral degrees in science education and mathematics education which in turn attracted both full-time and part-time doctoral students. In addition to the research-only $\mathrm{PhD}$, two professional doctorates were introduced in 1990 the Doctor of Science Education (ScEdD) and the Doctor of Mathematics Education (MathEdD) - comprising 30\% coursework and 70\% research thesis. These two professional doctorates proved to be very popular with part-time students working as full-time teachers.

National Key Centre for Teaching and Research in School Science and Mathematics (19881997)

During a nine-year period, the SMEC received additional funding from the Australian Research Council to improve the provisions for teaching and research for science and mathematics teachers in both primary and secondary schools at a national level. Subsequently, the Postgraduate Diploma and Master's degrees already offered in Perth, were taught in a number of interstate venues and also by distance education. This Australian Research Council initiative was the only Key Centre in the field of education.

The number of academic staff also grew with the appointment of Leslie Parker in 1991 as Assistant Director of the Key Centre - which had as a subtext 'Especially for Women' - a research interest of both Parker and Rennie. At the commencement of the Key Centre, and in keeping with the desire for improved connections between the Faculties of Science and 
Education, Geoff Giddings, who was then Head of Curriculum Studies, having taken over from Fraser when he became SMEC director, also held a joint appointment at SMEC.

Professional development institutes, short courses and seminars

An important Key Centre initiative for Australian science teacher education was the offering of Professional Development Institutes which provided opportunities for teachers to interact with eminent overseas visitors to the Centre (see Table 1). These institutes, which were offered during school holidays in Perth at Curtin University and in various locations around Australia, in New Zealand and also in Hawaii, gave science and mathematics teachers opportunities to develop practical strategies for improving their student learning. Oftentimes, the Institutes were run in conjunction with other universities around Australia and also New Zealand. Each institute had a teacher-as-researcher focus designed to help teachers to review their teaching methodologies and prepare them for conducting practical research in their own classrooms. As well, the institutes provided teachers with useful teaching ideas and curriculum materials which could be shared with colleagues in their own schools and regions.

Table 1 A sample of the professional development institutes led by many well known science educators (1990-1995)

\begin{tabular}{lll}
\hline \multicolumn{1}{c}{ Professional Development Institute } & \multicolumn{1}{c}{ Leader } & \multicolumn{1}{c}{ Home institution } \\
\hline $\begin{array}{l}\text { Constructivist teaching and learning } \\
\text { approaches }\end{array}$ & Ken Tobin & $\begin{array}{l}\text { Florida State University, } \\
\text { USA }\end{array}$ \\
$\begin{array}{l}\text { Promoting gender equity in the } \\
\text { classroom }\end{array}$ & Jane Butler Kahle & Miami University, USA \\
$\begin{array}{l}\text { Teaching science for understanding and } \\
\text { application }\end{array}$ & James Gallagher & $\begin{array}{l}\text { Michigan State University, } \\
\text { Using philosophy of science and }\end{array}$ \\
mathematics to improve teaching & Denis Phillips & USA \\
Science and technology in the science & Allan Griffiths & Memorial University of
\end{tabular}


curriculum

Students' alternative frameworks -

barriers to teaching and learning science

Communicating science, mathematics

and technology

Learning environments in

science/mathematics education

Using science centres in science and

technology education

Teaching and learning primary

mathematics: models and processes
Newfoundland, Canada

Reinders Duit

IPN at the University of Kiel,

Germany

Michael Gore

Theo Wubbels

National Science and

Technology Centre, Australia

University of Utrecht,

Netherlands

Goery Delacote

San Francisco

Exploratorium, USA

Lyn English
Queensland University of

Technology, Australia

In addition to the professional development institutes, short courses for primary school teachers interested in improving their teaching of science and mathematics were offered by John Wallace (appointed to the Key Centre/SMEC from the Western Australian Department of Education in 1992), Sandra Frid (also newly appointed to SMEC staff in 1990), Jim Shymansky (University of Iowa), and Tina Jarvis (University of Leicester). These short courses over several weeks enabled teachers to put into practice what they had learned one week and report at the next meeting.

When he became Director of SMEC, Fraser continued to encourage staff to present their research work not only at national conferences, but also at the prestigious research conferences in the USA. Subsequently, on a yearly basis, SMEC staff attended the annual conferences of the American Education Research Association, the National Association for Research on Teaching, the Australasian Science Education Research Association, and the Mathematics Education Research Group of Australasia; in this way their research work became well known. 
As noted above, one of the goals of the Key Centre was to provide full-time postgraduate students at the Centre and science and mathematics teachers who were part-time students with the opportunity to be taught by and meet academic colleagues from universities throughout the world. As an outcome of personal research collaborations worldwide and with SMEC staff becoming well known in the above professional associations, Fraser initiated a unique visiting scholar program. During a six-year period (1990-1995), the Key Centre had visits from academics from other Australian universities (Peter Fensham, Rob Walker, Cam McRobbie), and from universities in the USA (Jane Butler Kahle, Walter Doyle, Paul Joslin), England (Stephen Lerman, Jan Harding), Germany (Reinders Duit), Israel (Reuven Lazarowitz, Avi Hofstein), Canada (Alan Griffiths), Nigeria (Peter Okebukola), India (Anil Banerjee), Sweden (Ference Marton) and Norway (Svein Sjoberg). Many of these scholars, such as Kahle, Harding, as well as Jane Kenway and Shirley Sampson (the latter two from Australia), had research and development interests in gender issues and programs to enhance the participation of girls in science and mathematics. SMEC continues with its support of visiting academics and post-doctoral students, the majority of whom recently come from South-East Asia and North Asia, as well as visiting doctoral students from universities in Germany and Canada.

Increasing research activities

SMEC and Key Centre staff pursued numerous areas of research in science and mathematics education, including gender issues, upper school enrolment trends, classroom environment, factors linked with achievement, teaching and learning, leadership and professional development, conceptual change and constructivist teaching/learning styles. Since the early 1990s, the research programs of SMEC staff members have been supported by competitive research grants, primarily from the Australian Research Council, and the findings have consistently been published in peer-reviewed journals.

In the first three-year review of the Key Centre, the Review Panel chaired by Jim Gallagher noted that

“One of the strongest pieces of evidence of SMEC's national eminence is to be found in the result of the national Department of Education Employment and Training (DEET) Discipline Review of Teacher Education in Mathematics and Science. Despite the extremely small 
staffing level, SMEC is making a major contribution to research and other professional activities compared to other institutions around Australia. SMEC is, in fact, one of the two leading Australian institutions on both these important dimensions.”

The internationalisation of education - contributing to capacity building

By 1991, SMEC had almost 200 postgraduate students, two thirds of whom were enrolled in research oriented Master's and Doctoral degrees. At this time, from around 1985 to 1994 on a yearly basis SMEC hosted a cohort of 12-16 science and mathematics teachers from Indonesia who first completed a Postgraduate Diploma followed by Master's degrees by coursework and project. These teachers were instructors on a project entitled Permantapan Kerja Guru (PKG), meaning strengthening the work of teachers (Thair and Treagust 2003). The goals of the project were to provide leadership for in-service teacher development in Indonesia for science and mathematics teachers. Teachers were educated to use studentcentred learning that encouraged open communication with students and their active participation in classroom and laboratory activities. Similar groups of students studying mathematics education came from the Philippines.

By the mid-1990s, the Australian government had allowed universities to enrol overseas feepaying students. Consequently, SMEC began to attract an increasing number of overseas students, most of whom were full-time studying on Curtin campus. In addition, the possibility to enrol by a mixture of part-time and full-time studies was attractive to employees who did not wish to lose their staff for three or four years while undergoing full-time study. One such group comprised 20 South African university staff members who initially attended fulltime at Curtin University for a semester's coursework, with SMEC staff later going to South Africa to offer further coursework. When not in full-time study, the students returned to their employment to work and also to collect data for their research. Each student returned to Curtin for short periods during each year of enrolment to consult with his or her supervisors and have time for intensive writing. Consequently, over a period of five years, SMEC staff supervised the doctoral research of these South African academics who were from previously disadvantaged groups and in this way helped build up the human capacity of science and mathematics educators in South African universities and colleges. A similar arrangement 
resulted in 14 doctoral graduates from Thailand who work in Rajabhat Universities that prepare teachers for primary and secondary schools.

The initiative that involved SMEC staff members going to locations, referred to as nodes, where significant numbers of students were enrolled, involved several countries. The location with the largest numbers is in Miami Florida with teachers who work for the Miami-Dade County Pubic Schools, the fourth largest school district in the USA. Currently, groups of students meet together on a regular basis in Miami, New York, California, Dallas, New Zealand, Singapore, United Arab Emirates, and Tasmania. Students attending classes in these nodes receive support, motivation, and guidance from SMEC staff from the beginning of their research studies. Therefore, their specific needs are identified through early contact with staff. As might be expected, the location of these nodes changes with the changing demand of students wishing to commence SMEC's courses. Both the initiation of a new node and decisions about the nature of the postgraduate program offered in different nodes are based on extensive consultation with potential doctoral students and employer groups in that location regarding: the ideal timing of classes and visits for thesis support; the ideal set of coursework units to offer; and the range of thesis topics that will be offered for supervision. For example, an important focus in the Miami node is to provide leaders in science and mathematics education to replace the ageing leadership in Miami-Dade County Public Schools.

Students' appreciation of the flexibility of SMEC's postgraduate programs in providing parttime study opportunities for people residing at a distance is illustrated by the following comments of a Miami student: "I spent a great deal of time searching for a reputable, highly regarded doctoral program that allowed me to continue working as a full-time teacher in the Miami-Dade County Public School System. However, I was not able to find a local program that did not require me to take a semester leave from my job. These traditional types of doctoral programs do not meet the needs of women in today's society who may provide the major sources of income for their families. When I heard about Curtin's innovative doctoral program, I thought - Finally I have found a doctoral program for the 21st Century!”

Contributing to the professional leadership in science and mathematics education research 
One of the major goals of any graduate program in science and mathematics education is to provide renewal for classroom-based teachers who may also aspire to become leaders in schools or move to administrative positions within school systems. As already mentioned, this process is taking place in Miami-Dade County Public Schools; similarly in Western Australia many senior teachers and administrators are graduates of SMEC's programs. A second major goal is to engender the next generation of leaders in science education and mathematics education research. Indeed many active researchers hold Curtin Doctoral degrees - Brian Hand (University of Iowa); Joanne Goodell (Cleveland State University); Allan Harrison (University of Central Queensland); Sonya Martin (Drexel University); Cath Milne (New York University); Rebecca Nix (University of Texas at Dallas); Sue Stocklmayer (Australian National University); Daniel Tan (Nanyang Technological University, Singapore); Grady Venville (University of Western Australia); Bruce Waldrip (Monash University); Paul Webb (Nelson Mandela Metropolitan University); David Zandvleit (Simon Fraser University, Canada). Other leading science educators such as Steve Ritchie (Queensland University of Technology), John Wallace (University of Toronto), and Kate Scantlebury (University of Delaware) first earned their Master's degrees at SMEC prior to completing doctoral degrees elsewhere. By completing doctoral degrees in science education at SMEC, researchers such as Richard Coll and Penny Gilmer, who already held PhDs in science, switched from being chemistry researchers to chemistry/science education researchers.

\section{SMEC programs today}

SMEC is now in its $33^{\text {rd }}$ year. In the years since SMEC's foundation much has changed in the field of education. In the late 1970s, a postgraduate program that focussed on science and mathematics education degrees only was unique and the provision from the early 1980s to offer these programs through distance education added to the distinctiveness of the courses. In 2011, more than $90 \%$ of the SMEC student enrolment is by doctoral degrees offered locally to national and international students and through nodes and distance education to students in more than a dozen countries.

Now many universities in Australia and overseas offer postgraduate degrees in science and mathematics education and the existence of the Internet enables teachers to complete education degrees on-line as a common and accepted mode of delivery in higher education. Nevertheless, SMEC has maintained and enhanced its position as a leader in offering 
postgraduate degrees in science and mathematics education, with its nodes where SMEC staff visit and support students.

To maintain and enhance SMEC's capacity to support its teaching and research programs, several appointments have been made in the past five years. Jill Aldridge's research interests are in classroom learning environments and multicultural learning environments; she has special responsibilities for a teaching node in the United Arab Emirates; Bill Atweh's research interests are in the sociocultural aspects of mathematics education and critical and socially-responsible mathematics and science education; his many educational contacts with universities in Indonesia and the Philippines has resulted in an increasing number of students to SMEC from these countries. Vaille Dawson's research interests are in socio-scientific issues and argumentation in science education and adolescents' understandings and attitudes of biotechnology; she is helping build up the Master's by thesis degree offered to Perth teachers. Tony Rickards' research interests are in applications of technology to science and mathematics education and in the development of 3D virtual learning environments; he has responsibilities with Open Universities Australia and working with remote desert communities.

Academic recognitions and outputs

One of the world's most prestigious organisations for science education research - the National Association for Research in Science Teaching (NARST) in the USA - bestowed its highest form of recognition on three of Curtin's staff. Fraser was awarded NARST's 2003 Distinguished Contributions to Science Education through Research Award. The same Award was given to Treagust and Rennie in, respectively, 2006 and 2009. Curtin is the only university in the world with three recipients of this prestigious lifetime achievement award. Tobin, who previously had an appointment at Curtin, is also a recipient of this prestigious award.

Currently, SMEC enjoys the status of one of Curtin's elite University Research Institutes and provides a high-quality learning environment for large numbers of mainly part-time research students, from all Australian states and many countries around the world, including USA, 
Singapore, New Zealand, South Africa, and Thailand. During the academic years from 2007 to 2010, an average of 12 Master's students and 28 doctoral students completed their degrees each year.

SMEC's approach emphasizes the interrelatedness of enrolled classes, thesis supervision, research and teaching. The Centre views its supervision of theses as closely linked to excellence in both teaching and research. For example, many of the graduates have become cutting-edge researchers in fields such as learning environments, professional development, concept learning, test development, and qualitative methods of enquiry. Furthermore, there is a belief in SMEC that excellence in supervision derives from staff conducting research into their own supervision and teaching practice. Students are given up-to-date supervision through encouragement to be involved in the research process by attending national and international conferences and publishing with their supervisors.

An obvious question to ask is how well has SMEC fulfilled the intentions of its founder, John de Laeter. As is illustrated in this short history, these intentions have been largely fulfilled providing a strong basis for continued productivity and considerations for future directions. The present status of SMEC is a result of: some wise decisions about the appointment of directors, each of whom in his time moved the Centre to a higher degree of activity, first locally, then nationally and then internationally; being the first and still only Key Centre in education at a time when the focus on gender equity in science and mathematics was of high concern; and increasing the research activities and internationalisation by enrolments of overseas students and visiting academics. All of these outcomes occurred during many changes in Australian higher education over a period of 30 years. Whether SMEC can maintain its place as a contributor to science education and mathematics education research nationally and internationally in the next 30 years will depend on, as in the past, many wise decisions being made in a changing landscape of higher education. New productive staff members have been appointed to SMEC to continue the teaching and research programs. However, in many countries, former postgraduate centres for science education and mathematics education now no longer exist due to changes in academic structures and/or financial constraints. So events outside the SMEC's activities may document its fate. According to Tobin (2010), waxing and waning of influences is a normal state of development in science education. To date, as noted in this paper, SMEC has contributed to the globalization of science and mathematics education with graduates—several of whom are in strong leadership positions-in more than 20 countries. These SMEC graduates continue to 
influence the development of research and teaching in science and mathematics education in their own countries and also in other nations who send students overseas for postgraduate studies.

\section{References}

Boud, D. J. \& de Laeter, J. R. (1978). Continuing development in science education: A course for the professional development of experienced science teachers. The Australian Science Teachers Journal, 24(3), 69-72, 67.

Commonwealth Advisory Committee on Standards for Science Facilities in Independent Secondary Schools (1971). Gardiner E. D., de Laeter, J. R., Denny P. F., Field T. W., McConchie E. M., Selby-Smith R., Smith R. T., Whitley A. (Eds.), The design of science rooms. Canberra ACT: Australian Government Printing Services.

Commonwealth Advisory Committee on Standards for Science Facilities in Independent Secondary Schools (1974). Gardiner E. D., de Laeter J. R., Denny PF, Field T. W., Selby-Smith R, Smith R.T., Whitley A., Wordsworth O. J. (Eds.), Science apparatus list for secondary schools. Canberra: Australian Government Printing Services.

Thair, M. \& Treagust, D. F. (2003). A brief history of science teacher professional development initiative in Indonesia and the implications for centralised teacher development. International Journal of Educational Development, 23, 201-213.

Tobin, K. (2010). Global reproduction and transformation of science education. Cultural Studies of Science Education, 6, 127-142.

White, M. (1990). Watts at WAIT: the establishment of Curtin University of Technology. Journal of Tertiary Educational Administration, 12, 273-287.

Wordsworth O. J., Field T. W., de Laeter J. R., \& Wilmott M. R. (1975.) Science teacher development. Canberra: Australian Government Printing Services. 